\title{
Hubungan Pola Asuh Orang Tua terhadap Disiplin Belajar Siswa di SMPN Kubung
}

Maliki

Guru SMP Negeri 7 Kubung, Kab. Solok

\begin{abstract}
Abstrak
Penelitian ini dilatarbelakangi oleh persoalan-persoalan disiplin siswa SMPN 7 Kubung dalam belajar, seperti: siswa datang terlambat, tidak mengerjakan pekerjaan rumah (PR), persiapan belajar kurang baik, kurang memperhatikan materi pelajaran, dan menggunakan asesoris yang tidak diperbolehkan. Tujuan penelitian ini untuk mendeskripsikan tiga hal, pola asuh orang tua, disiplin belajar siswa, dan hubungan antara pola asuh orang tua terhadap disiplin belajar siswa SMPN 7 Kubung. Jenis penelitian ini adalah penelitian korelasional melalui pendekatan kuantitatif. Jumlah sampel dalam penelitian ini berjumlah 24 orang. Selanjutnya, instrumen dalam pengumpulan data penelitian ini menggunakan angket. Teknik analisis data untuk penelitian ini menggunakan rumus korelasi produk moment. Simpulan penelitian ini ada tiga, yaitu (1) pola asuh orang tua siswa memiliki nilai rata-rata baik, (2) disiplin belajar siswa SMPN 7 Kubung dikategorikan cukup baik, dan (3) tidak ada hubungan antara pola asuh orang tua terhadap disiplin belajar siswa SMPN 7 Kubung.
\end{abstract}

Kata kunci: pola asuh orang tua, disiplin belajar

Copyright (C) 2017 IICET (Indonesia) - All Rights Reserved

Indonesian Institute for Counseling, Education and Theraphy (IICET)

\section{PENDAHULUAN}

Pola asuh merupakan cara yang dilakukan orang tua untuk mendidik anak dan cara tersebut tidak terlepas dari pengaruh karakter individu (Edwards, 2006:48). Sejalan dengan penjelasan Edwards, Gunarsa (2002:37) mengatakan bahwa pola asuh adalah cara orang tua bertindak, berinteraksi, mendidik, dan membimbing anak sebagai suatu aktivitas yang melibatkan banyak perilaku tertentu secara individual maupun bersama- sama sebagai serangkaian usaha aktif untuk mengarahkan anak. Hubungan antara orang tua memperkenalkan pada aturan dan norma yang berlaku dan mendekatkan anak dengan keluarga.

Menurut Safitri, Y., \& Hidayati, E. (2013) pola asuh orang tua adalah pola perilaku yang diterapkan pada anak dan bersifat relative konsisten dari waktu ke waktu. Kemudian Apriastuti, D. A. (2013) juga menjelaskan pola suh merupakan bentuk-bentuk yang diterapkan dalam rangka merawat, memelihara, membimbing, melatih dan memberikan pengaruh. Lebih lanjut, Is Pratiwi, N. (2012) mengungkapkan pola asuh adalah suatu suatu proses interaksi total orang tua dan anak, meliputi kegiatan seperti memelihara, memberi makan, melindungi dan mengarahkan tingkah laku anak selama masa perkembangan anak serta bagaimana cara orangtua mengkomunikasikan afeksi (perasaan). Pola asuh orang tua yang tidak terlalu mengekang, maka anak akan menjadi anak yang berinisiatif, percaya diri dan mampu menjalin hubungan interpersonal yang positif Fortuna, F. (2012).

Hubungan orang tua dan anak mempengaruhi perkembangan moral anak (Santrock, 2007:133). Pola asuh orang tua dalam penelitian ini merupakan cara mendidik anak yang terbagi dalam dua dimensi, yaitu 
dimensi kontrol yang terdiri dari pembatasan, tuntutan, sikap ketat, campur tangan, dan kekerasan sewenangwenang. Dimensi kehangatan meliputi perhatian orang tua terhadap kesejahteraan anak, responsivitas orang tua terhadap kebutuhan anak, meluangkan waktu bersama anak, mrnunjukkan rasa antusias atas tingkah laku yang diperlihatkan anak, dan peka terhadap kebutuhan emosi anak.

Yusuf (2004:48-50) mengemukakan bahwa sikap dalam pola asuh orang tua terbagi menjadi beberapa macam, terdiri dari overprotection (terlalu melindungi). Menurut Kusumaningtyas, L. E. (2015) overprotektif berasal dari kata over dan protektif, over berarti berlebihan sedangkan protektif berarti emlindungi. Pola asuh overprotection yaitu terlalu berlebihan dalam memberikan bantuan, terlalu mengawasi anak. Menurut Wahib, A. W. A. (2015) orang tua yang tidak bekerja sebaiknya tidak terlalu over protektif, sehingga anak mampu untuk bersikap mandiri. Dipertegas oleh Sutanto, B. C. (2014) anak yang dibesarkan dengan pola asuh over protektif mereka akan cenderung memiliki rasa takut yang tidak wajar.

Permissiveness (pembolehan), yaitu memberikan peluang kepada anak untuk berpendapat, memberikan kesempatan anak untuk berusaha. Rejection (penolakan) yaitu orang tua tidak peduli terhadap anak, bersikap masa bodoh dan kurang memperhatikan kesejahteraan anak. Acceptance (penerimaan) yatu memberikan kasih sayang, memiliki hubungan yang hangat dengan anak dan terbuka serta memotivasi anak. Domination (mendominasi anak) yaitu semua yang dilakukan harus dengan ijin orang tua, meskipun sebenarnya anak bisa memutuskan apa yang harus dilakukan tetapi orang tua ikut campur. Submission (penyerahan), yaitu membiarkan anak melakukan apapun yang diinginkan, orang tua tidak ada usaha untuk merubah perilaku anak. Punitiveness (terlalu disiplin) yaitu orang tua yang sering memberikan hukuman, meskipun hal tersebut dapat dilakukan dengan nasihat.

McMahon et al., (Thalib, 2013:72-73) mengklasifikan pola asuh dalam tiga katagori yaitu otoritatif, diktatorial, dan permisif. Pada pola asuh diktatorial, orang tua menunjukkan sikap yang kaku, tidak fleksibel, tidak percaya bahwa anak dapat membuat keputusan sendiri tentang sesuatu yang akan dilakukan. Akibatnya, anak tidak bisa mengambil keputusan yang berguna baginya dan sering kesusahan dalam berhubungan dengan teman sebaya. Pada prinsipnya pola asuh ini sesuai dengan pola asuh otoriter yang dikemukakan Edward, begitu juga degan pola asuh otoritatif. Pola asuh permisif cenderung mengabaikan anak, tidak konsisten dalam menerapkan aturan, memberikan perlindungan dan kasih sayang yang berlebihan. Akibatnya anak cenderung tidak banyak belajar tentang perilaku yang dapat diterima dan tidak diterima (unacceptabel behaviour), tidak memiliki disiplin diri, cenderung kurang percaya diri, impulsif, sulit mengambil keputusan tentang diri sendiri.

Selaras dengan macam-macam pola asuh di atas, Ayu (Aqib, 2011:66) menyebutkan tiga macam pola asuh yaitu pola asuh demokratis, pola asuh otoriter, dan pola asuh permisif yang akan membentuk perilaku yang berbeda-beda. Pola asuh demokratis menghasilkan anak yang dapat mengontrol diri, mempunyai hubungan baik dengan teman, dan terbuka pada orang tua. Pola asuh otoriter akan membentuk perilaku anak yang tertekan, pendiam, cemas, dan menarik diri. Sedangkan pola asuh permisif menghasilkan karakteristik anak yang manja, ingin menang sendiri, kurang percaya diri, salah bergaul, dan kurang kontrol diri.

Selanjutnya, Lerner \& Hultsch (dalam Desmita, 2005:144-145) menyatakan bahwa terdapat tiga macam pola asuh yaitu demokratif, otoriter dan permisif. Pola asuh demokratif (authoritative parenting) adalah gaya pengasuhan yang memperlihatkan pengawasan ekstra ketat terhadap tingkah laku anak, responsif, menghargai, dan menghormati pemikiran, perasaan, serta mengikutsertakan anak dalam mengambil keputusan. Anak yang di didik dengan pengasuhan otoritatif cenderung lebih percaya pada diri sendiri, pengawasan diri sendiri, lebih mudah bergaul dengan teman sebayanya. Pengasuhan ini memiliki moral standar, kematangan psikososial, kemandirian, sukses dalam belajar, dan bertanggung jawab secara sosial. 
Pola asuh otoriter (authoritarian parenting), yaitu gaya pengasuhan yang menuntut dan membatasi anak untuk mengikuti perintah perintah orang tua. Orang tua yang otoriter memiliki batasan-batasan yang tegas dan tidak memberi peluang yang besar untuk anak-anak dalam mengemukakan pendapat. Orang tua cenderung bersikap sewenang-wenang dan tidak demokratis dalam membuat keputusan, memaksakan peran atau pandangan kepada anak atas dasar kekuasaan sendiri, kurang menghargai pemikiran dan perasaan anak. Anak dari orang tua otoriter cenderung bersifat curiga pada orang lain dan kurang merasa bahagia dengan diri sendiri, merasa canggung berhubungan dengan teman sebaya, canggung menyesuaikan diri pada awal masuk sekolah, ketakutan, agresif, tidak mampu memulai aktivitas, dan memiliki prestasi belajar yang rendah dibanding siswa lain.

Pola asuh permisif (permissive parenting), gaya pengasuhan ini dibagi menjadi dua jenis. Pertama, pengasuhan permissive-indulgent yaitu gaya pengasuhan dimana orang tua sangat terlibat dalam kehidupan anak tapi menetapkan batas atau kendali pada anak. Pengasuhan ini diasosiasikan dengan kurangnya pengendalian anak, karena orang tua permissive-indulgent cenderung membiarkan anak melakukan semua yang diinginkan sehingga anak tidak belajar mengendalikan perilakunya sendiri, mendominasi, tidak menaati aturan, kesulitan bergaul dengan teman sebaya, dan anak selalu berharap semua kemauannya dituruti. Kedua, pengasuhan permissive-indifferent yaitu suatu gaya pengasuhan dimana orang tua sangat tidak terlibat dalam kehidupan anak. Anak yang dibesarkan dengan pengasuhan permissive-indifferent cenderung kurang percaya diri, pengendalian diri buruk, tidak memiliki kemampuan sosial, tidak mandiri, tidak dewasa, kemungkinan terasing dari keluarga, dan rasa harga diri rendah.

Menurut Fortuna, F. (2012) pola asuh permisif mempunyai ciri-ciri: 1) kontrol orang tua kurang, 2) bersifat longgar atau bebas, 3) anak kurang dibimbing dalam mengatur dirinya, dan 4) hampir tidak menggunakan hukuman. Selanjutnya, Khairunnisa, A. (2013) menjelaskan pola asuh permisif merupakan pola asuh yang memberikan kebebasan pada anak tanpa hambatan aturan dan norma. Sependapat dengan Fitriana, V. (2011) bahwa pola asuh permisif anak bebas dalam berbuat dan bertingkah laku.

Disiplin adalah tepat waktu, tidak datang terlambat, taat pada peraturan yang berlaku, menjalankan tudas sesuai jadwal yang ditentukan (Aqib, 2012:5). Selanjutnya, Sulistyowati (2012:30) menyatakan bahwa disiplin adalah tindakan yang menunjukkan perilaku tertib dan patuh pada berbagai ketentuan dan peraturan. Disiplin juga sebagai cerminan dari ketaatan, kepatuhan, ketertiban, kesetiaan, ketelitian, dan keteraturan perilaku seseorang terhadap norma yang berlaku serta dikerjakan dengan peuh kesadaran, ketekunan, dan tanpa paksaan (Zuariah, 2007:69-83). Disiplin adalah keteraturan atau ketaatan seseorang terhadap tata tertib atau kaidah-kaidah hidup lainnya. Disiplin adalah sikap dan perilaku sebagai cerminan dari ketaatan, kepatuhan, ketertiban, kesetiaan, ketelitian, dan keteraturan perilaku seseorang terhadap norma dan aturan yang berlaku. Serta dikatakan bahwa menumbuhkan sikap disiplin usia sekolah dasar merupakan satu dari 12 perilaku minimal yang harus dikembangkan usia sekolah dasar. Beberapa sikap disiplin yang dapat diterapkan pada anak yaitu disiplin dalam makan, disiplin melaksanakan sholat tepat waktu, disiplin istirahat, disiplin bangun tidur, dan disiplin menyebrang jalan melalui zebra cross (Marijan, 2012:74). Ciri-ciri disiplin belajar di sekolah, Khalsa (2008:70-71) yaitu (a) masuk kelas sesuai jadwal yang ditetapkan, (b) melakukan kegiatan di sekolah sesuai dengan petunjuk guru dan aturan sekolah, (c) melaksanakan piket kelas sebelum kegiatan belajar dimulai, (d) meminta izin jika berhalangan hadir mengikuti kegiatan belajar di sekolah, (e) menyapa guru dan teman saat bertemu, dan (f) mengikuti upacara tiap hari senin atau upacara hari nasional lainnya dengan tertib.

Berdasarkan penjelasan di atas, maksud dari disiplin belajar dalam penelitian ini yaitu persiapan belajar yang baik, perhatian terhadap materi pelajaran, menyelesaikan tugas tepat pada waktunya, taat dan patuh terhadap peraturan sekolah, dan merencanakan jadwal belajar. Hal tersebut bisa diuraikan yaitu siswa dapat mengatur waktu dengan baik, masuk kelas sesuai jadwal yang ditetapkan, melakukan kegiatan di sekolah sesuai dengan petunjuk guru dan aturan sekolah, melaksanakan piket kelas sebelum kegiatan belajar 
dimulai, meminta izin jika berhalangan hadir mengikuti kegiatan belajar di sekolah. Berdasarkan observasi di SMPN 7 Kubung pada tanggal 2 Februari 2017 terdapat beberapa permasalahan, yaitu: (a) siswa tinggal di kelas yang sama, (b) siswa datang terlambat, (c) tidak mengerjakan pekerjaan rumah (PR), (d) persiapan belajar kurang baik, (e) kurang memperhatikan materi pelajaran, (f) kurang taat dan patuh pada peraturan sekolah, (g) tidak ada jadwal belajar, (h) hubungan antara orang tua dengan anak kurang terjalin dengan baik. Berdasarkan fenomena tersebut, maka penting dilakukan penelitian untuk mengetahui hubungan antara pola asuh orang tua terhadap disiplin belajar siswa di SMPN 7 Kubung.

\section{METODOLOGI}

Jenis penelitian ini adalah penelitian korelasional melalui pendekatan kuantitatif. Dalam penelitian ini, dideskripsikan hubungan antara pola asuh orang tua terhadap disiplin belajar siswa SMP Negeri 7 Kubung. Populasi penelitian ini adalah siswa-siswi kelas VII, VIII, dan IX SMP Negeri 7 Kubung yang terdaftar pada tahun pelajaran 2016/2017 dengan jumlah 138 orang siswa, yang tersebar dalam enam kelas. Selanjutnya, jumlah sampel dalam penelitian ini berjumlah 24 orang yang diambil melalui teknik proportional random sampling (Arikunto, 2010). Selanjutnya, instrumen dalam pengumpulan data penelitian ini menggunakan angket. Angket tersebut terdiri atas 15 butir pernyataan untuk memperoleh data pola asuh orang tua sedangkan angket disiplin belajar siswa terdiri atas 41 pernyataan. Teknik analisis data untuk penelitian ini menggunakan rumus korelasi produk moment.

\section{HASIL DAN PEMBAHASAN \\ Pola Asuh Orang Tua Siswa SMP Negeri 7 Kubun}

Pola asuh orang tua merupakan bagian yang penting dalam menunjang perkembangan anak. Hal tersebut sesuai dengan pendapat Aqib (2011:60-61) yang mengemukakan bahwa terdapat tiga kebutuhan pokok mengembangkan kecerdasan, antara lain kebutuhan fisik-biologis terutama untuk pertumbuhan otak, sistem sensorik dan motorik seperti gizi yang diberikan untuk anak, kebutuhan emosi kasih sayang yang mempengaruhi kecerdasan emosi, inter dan intrapersonal seperti melindungi, menghargai anak, memberikan perhatian, tidak mengutamakan hukuman, serta memberikan rasa aman dan nyaman.

Edwards (2006:83) mengemukakan bahwa faktor yang mempengaruhi pola asuh orang tua adalah ketegangan yang dirasakan orang tua atau kesibukan orang tua yang padat bisa mempengaruhi konsistensi orang tua dalam mendidik anak dan orang tua dalam mendidik anak dipengaruhi oleh pola asuh pada saat orang tua dibesarkan. Berdasarkan hasil analisis data, dapat dijelaskan bahwa rata-rata peran orang tua cukup baik di keluarga. Orang tua bersikap cuek kepada anak dengan persentase 39\% dan orang tua membiarkan anaknya melakukan semua keinginannya dengan persentase 53\%. Selanjutnya, pada indikator orang tua membiarkan anaknya bila melakukan kesalahan di sekolah mencapai persentase $37 \%$ sedangkan orang tua menerima prestasi yang di dapat anaknya mencapai persentase $83 \%$. Orang tua memberikan persetujuan terhadap keinginan anaknya dengan persentase $67 \%$ dan di dalam keluarga, orang tua tidak memberikan aturan-aturan kepada anaknya dengan persentase $54 \%$.

Selanjutnya, orang tua bersikap hangat dan sangat menyayangi anak mencapai persentase $96 \%$ dan orang tua bersikap ramah dan sabar kepada anak dengan persentase $87 \%$. Pada indikator orang tua mengajak anak untuk memecahkan masalah secara bersama-sama mencapai persentase $86 \%$ sedangkan orang tua memberikan masukan dan arahan apabila anaknya mempunyai masalah mencapai persentase $65 \%$. Kemudian, orang tua menyisihkan sebagian waktunya untuk berkumpul bersama anak-anaknya dengan persentase $97 \%$ sedangkan orang tua tidak mengajak anaknya untuk makan bersama di rumah mencapai persentase 93\%. Orang tua tidak menuntut anaknya untuk melakukan semua tugas rumah tepat pada waktunya dengan persentase 59\%, orang tua menghargai setiap kemampuan yang dimiliki anaknya dengan persentase $67 \%$, dan saat kesulitan mengerjakan ulangan, saya bertanya pada teman dengan persentase $96 \%$. 
Berdasarkan analisis tersebut, dapat disimpulkan bahwa indikator saat kesulitan mengerjakan ulangan, saya bertanya pada teman, orang tua tidak mengajak anaknya untuk makan bersama di rumah, orang tua menyisihkan sebagian waktunya untuk berkumpul bersama anak-anaknya, orang tua mengajak anak untuk memecahkan masalah secara bersama-sama, orang tua bersikap hangat dan sangat menyayangi anak, orang tua bersikap ramah dan sabar kepada anak, dan orang tua menerima prestasi yang di dapat anaknya memperoleh nilai yang sangat baik. Artinya, pola asuh orang tua pada indikator tersebut sangat tampak dan tidak ada indikasi bahwa orang tua tidak memberikan perhatian di rumah.

\section{Disiplin Belajar Siswa SMP Negeri 7 Kubung}

Disiplin belajar siswa dapat diketahui dengan ciri-ciri, yaitu masuk kelas sesuai jadwal yang ditetapkan, melakukan kegiatan di sekolah sesuai dengan petunjuk guru dan aturan sekolah, melaksanakan piket kelas sebelum kegiatan belajar dimulai, meminta izin jika berhalangan hadir mengikuti kegiatan belajar di sekolah, menyapa guru dan teman saat bertemu, dan mengikuti upacara setiap hari senin atau upacara hari nasional lainnya degan tertib (Khalsa, 2008:70-71). Berdasarkan pendapat di atas, disiplin belajar perlu ditegakkan, jika disiplin siswa sudah terbentuk dengan baik, maka disiplin bisa menjadi karakter siswa. karakter disiplin akan tetap melekat pada diri siswa. Hal tersebut sesuai dengan pendapat Koesoma (2007:233-240) yang menyatakan bahwa disiplin merupakan locus education yaitu sarana siswa belajar moral agar menjadi manusia aktif di lingkungan sosial masyarakat. Disiplin tersebut terlihat dari kehadiran siswa di sekolah. Jadi melalui disiplin di sekolah, sikap disiplin akan berlaku pada kehidupan bermasyarakat yang diterapkan siswa saat dewasa.

Berdasarkan hasil analisis data, dapat diuraikan bahwa disiplin belajar siswa dilihat dari indikator saat bel masuk kelas berbunyi, langsung menuju tempat duduk dengan persentase $81 \%$, setelah masuk kelas, saya jalan-jalan di kelas sampai guru datang dengan persentase $61 \%$, mempersiapkan buku pelajaran tanpa menunggu arahan dari guru dengan persentase $78 \%$, meminjam alat tulis kepada teman karena tidak membawa dengan persentase $63 \%$, mengingatkan teman untuk tidak gaduh dengan persentase $60 \%$. Selain itu, pada indikator hanya diam meskipun kurang jelas dengan penjelasan guru mencapai persentase $61 \%$, saat pelajaran berlangsung, memperhatikan pelajaran dengan baik dengan persentase $85 \%$, ketika terdapat teman yang bergurau saat pelajaran, siswa ikut bergurau dengannya dengan persentase $61 \%$, saat diberi pertanyaan oleh guru, siswa bisa menjawab dengan persentase $72 \%$, dan diperingatkan guru untuk tidak bermain-main di kelas dengan persentase $60 \%$.

Hasil analisis data menunjukkan bahwa siswa mengerjakan sendiri tugas yang diberikan guru dengan persentase $78 \%$, melihat pekerjaan teman saat menemukan kesulitan mengerjakan tugas dengan persentase $67 \%$, mengumpulkan tugas yang telah selesai dikerjakan tepat waktu dengan persentase $83 \%$, dan saat pelajaran berlangsung, siswa keluar masuk kelas untuk meraut pensil dengan persentase $39 \%$. Selain itu, siswa masih sempat bermain dengan teman dengan persentase 57\%, berseragam rapi dan bersih saat berangkat ke sekolah dengan persentase $97 \%$, tidak izin ketika tidak bisa berangkat sekolah dengan persentase $50 \%$, dan tidak pulang terlebih dahulu sebelum dipersilahkan oleh guru dengan persentase $89 \%$. Kemudian, pada indikator saat terlambat, tanpa mengetuk pintu siswa langsung masuk kelas mencapai persentase $51 \%$ dan tanpa sepengetahuan guru, siswa makan di kelas mencapai persentase 53\%.

Pada indikator siswa dibangunkan orang tua untuk bersiap-siap ke sekolah mencapai persentase $76 \%$, ketika jam istirahat berakhir, siswa membawa makanan ke dalam kelas dengan persentase $53 \%$, belajar paling sedikit 1 jam setiap hari dengan persentase $65 \%$, laci meja saya bersih dari sampah dengan persentase $89 \%$, memiliki alat tulis cadangan, jadi tidak perlu meninggalkan kelas ketika bolpen atau pensil rusak dengan persentase $69 \%$. Lalu, untuk indikator belajar setiap hari tanpa disuruh orang tua dengan persentase $72 \%$, lebih suka bermain-main dengan persentase $53 \%$, bertanya pada teman $68 \%$, mempersiapkan buku yang akan dibawa ke sekolah dengan persentase $85 \%$, dan jadwal pelajaran untuk esok hari sudah disiapkan ibu mencapai persentase $40 \%$. 
Hasil analisis menunjukkan bahwa siswa membawa semua buku pelajaran setiap hari dengan persentase $56 \%$, meminta orang tua mengantarnya ke sekolah untuk mengantar buku yang tertinggal dengan persentase $35 \%$, bermain lempar-lemparan dengan teman ketika pelajaran dengan persentase $47 \%$, ikut mengerjakan tugas kelompok dengan persentase $79 \%$, berusaha menemukan jawaban yang paling tepat dengan persentase $78 \%$, dan lupa mengerjakan pekerjaan rumah mencapai persentase 67\%. Selain itu, siswa kurang memperhatikan pelajaran sehingga terlambat mengumpulkan tugas dengan persentase 53\%, tidur siang agar tidak mengantuk ketika belajar dengan persentase $58 \%$, bermain setelah pulang sekolah sampai sore hari dengan persentase $47 \%$, belajar ketika ada pekerjaan rumah dengan persentase $71 \%$, dan peralatan alat tulis siswa lengkap mencapai persentase $82 \%$.

Berdasarkan hasil analisis data, dapat disimpulkan bahwa indikator peralatan alat tulis siswa lengkap, laci meja saya bersih dari sampah, mempersiapkan buku yang akan dibawa ke sekolah, berseragam rapi dan bersih saat berangkat ke sekolah, mengumpulkan tugas yang telah selesai dikerjakan tepat waktu, tidak pulang terlebih dahulu sebelum dipersilahkan oleh guru, memperhatikan pelajaran dengan baik, dan langsung menuju tempat duduk memperoleh nilai rata-rata yang sangat baik. Artinya, disiplin belajar siswa cukup baik, namun ada beberapa indikator yang berkaitan dengan sikap dan pelanggaran-pelanggaran fasilitas belajar menunjukkan hasil yang tidak baik.

\section{Hubungan Pola Asuh Orang Tua terhadap Disiplin Belajar Siswa SMP Negeri 7 Kubung}

Hubungan antara pola asuh orang tua terhadap disiplin belajar siswa SMP Negeri 7 Kubung dicari dengan menggunakan rumus korelasi produk moment. Data mengenai pola asuh orang tua dimasukkan ke dalam variabel $\mathrm{X}$ dan data disiplin belajar dimasukkan ke dalam variabel Y. Data mengenai nilai masingmasing variabel pada lampiran dimasukkan ke dalam tabel berikut ini.

Tabel. Hubungan Pola Asuh Orang Tua terhadap Disiplin Belajar Siswa SMP Negeri 7 Kubung

\begin{tabular}{|c|c|c|c|c|c|c|}
\hline No & $\begin{array}{c}\text { Kode } \\
\text { Sampel }\end{array}$ & $\mathbf{X}$ & $\mathbf{Y}$ & $\mathbf{X}^{2}$ & $\mathbf{Y}^{2}$ & $\mathbf{X Y}$ \\
\hline 1 & 2 & 3 & 4 & 5 & 6 & 7 \\
\hline 1 & 01 & 76 & 67 & 5.776 & 4.489 & 5092 \\
\hline 2 & 02 & 69 & 64 & 4.761 & 4.096 & 4416 \\
\hline 3 & 03 & 73 & 70 & 5.329 & 4.900 & 5110 \\
\hline 4 & 04 & 73 & 64 & 5.329 & 4.096 & 4672 \\
\hline 5 & 05 & 71 & 62 & 5.041 & 3.844 & 4402 \\
\hline 6 & 06 & 78 & 58 & 6.084 & 3.364 & 4524 \\
\hline 7 & 07 & 71 & 64 & 5.041 & 4.096 & 4544 \\
\hline 8 & 08 & 71 & 65 & 5.041 & 4.225 & 4615 \\
\hline 9 & 09 & 73 & 66 & 5.329 & 4.356 & 4818 \\
\hline 10 & 10 & 67 & 69 & 4.489 & 4.761 & 4623 \\
\hline 11 & 11 & 73 & 70 & 5.329 & 4.900 & 5110 \\
\hline 12 & 12 & 67 & 67 & 4.489 & 4.489 & 4489 \\
\hline 13 & 13 & 73 & 69 & 5.329 & 4.761 & 5037 \\
\hline 14 & 14 & 62 & 58 & 3.844 & 3.364 & 3596 \\
\hline 15 & 15 & 73 & 61 & 5.329 & 3.721 & 4453 \\
\hline 16 & 16 & 82 & 65 & 6.724 & 4.225 & 5330 \\
\hline 17 & 17 & 76 & 71 & 5.776 & 5.041 & 5396 \\
\hline 18 & 18 & 67 & 67 & 4.489 & 4.489 & 4489 \\
\hline 19 & 19 & 78 & 60 & 6.084 & 3.600 & 4680 \\
\hline 20 & 20 & 69 & 67 & 4.761 & 4.489 & 4623 \\
\hline 21 & 21 & 69 & 67 & 4.761 & 4.489 & 4623 \\
\hline 22 & 22 & 69 & 69 & 4.761 & 4.761 & 4761 \\
\hline 23 & 23 & 80 & 67 & 6.400 & 4.489 & 5360 \\
\hline
\end{tabular}




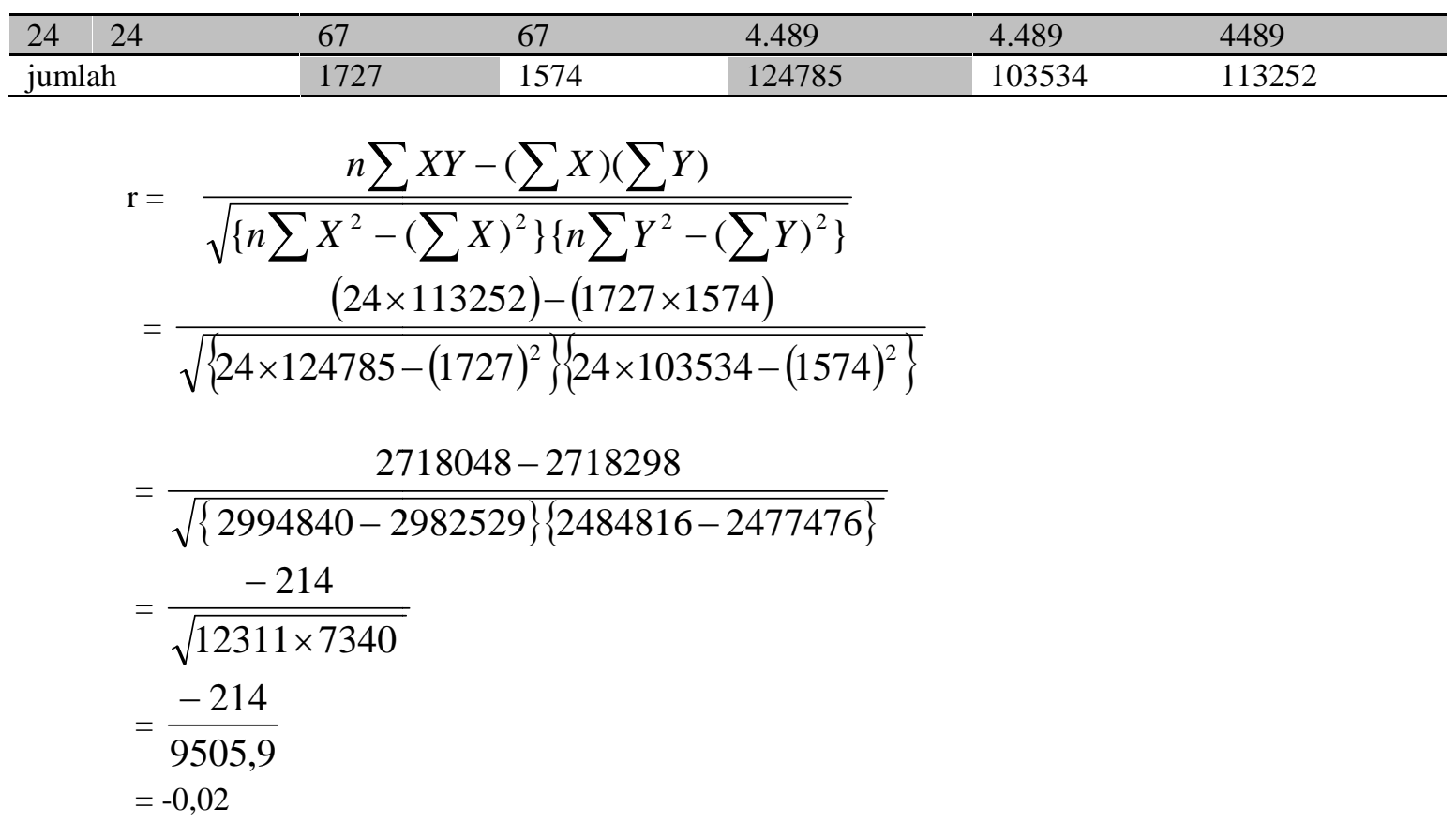

Berdasarkan nilai r yang diperoleh, diketahui bahwa nilai korelasi kedua variabel dalam penelitian ini adalah -0,02. Untuk menafsirkan keberartian hubungan antara kedua variabel, setelah nilai koefisien korelasi diperoleh, kemudian dilanjutkan dengan menguji keberartian hipotesis dengan menggunakan rumus uji $\mathrm{t}$ berikut ini.

$$
\begin{aligned}
t & =r \frac{\sqrt{n-2}}{\sqrt{1-r^{2}}} \\
& =-0,02 \frac{\sqrt{22}}{\sqrt{1-(-0,02)^{2}}} \\
& =\frac{4,69}{1,04} \times-0,02 \\
& =-0,09
\end{aligned}
$$

Setelah $\mathrm{t}$ hitung diperoleh, dilanjutkan dengan uji t yaitu membandingkan nilai $\mathrm{t}$ hitung dengan tabel pada taraf signifikan 95\% adalah 1,72 dengan derajat kebebasan n-2. Dari hasil pengujian hipotesis, dapat disimpulkan bahwa tidak terdapat hubungan antara pola asuh orang tua terhadap disiplin belajar siswa SMP Negeri 7 Kubung pada taraf signifikan 95\% dengan derajat kebebasan n-2. Dengan demikian, $\mathrm{H}_{0}$ dalam penelitian ini diterima, sedangkan $\mathrm{H}_{1}$ diterima karena hasil pengujian membuktikan bahwa $\mathrm{t}$ hitung lebih kecil dari t tabel yaitu -0,09 lebih kecil dari 1,72.

Hasil analisis data menunjukkan bahwa tidak ada hubungan yang signifikan antara pola asuh dengan disiplin belajar siswa di SMPN 7 Kubung. Hal ini membuktikan bahwa terdapat beberapa faktor, seperti: faktor dari anak itu sendiri dan pengaruh lingkungan yang lebih berpengaruh terhadap disiplin belajar siswa. Aqib, (2011:66) menyebutkan tiga macam pola asuh yaitu pola asuh demokratis, pola asuh otoriter, dan pola asuh permisif yang akan membentuk perilaku yang berbeda-beda. Pola asuh demokratis menghasilkan anak yang dapat mengontrol diri, mempunyai hubungan baik dengan teman, dan terbuka pada orang tua. Pola asuh otoriter akan membentuk perilaku anak yang tertekan, pendiam, cemas, dan menarik diri. Sedangkan 
pola asuh permisif menghasilkan karakteristik anak yang manja, ingin menang sendiri, kurang percaya diri, salah bergaul, dan kurang kontrol diri.

Berdasarkan hasil analisis data, dapat dipahami bahwa orang tua cenderung membiarkan anaknya dibesarkan oleh lingkungan sehingga terjadi pengaruh besar terhadap perilakunya. Siswa mendapat banyak pengaruh negatif dari lingkungan sehingga terjadi ketidakdisiplinan terhadap pembelajaran. Pola asuh permisif cenderung mengabaikan anak, tidak konsisten dalam menerapkan aturan, memberikan perlindungan dan kasih sayang yang berlebihan. Akibatnya anak cenderung tidak banyak belajar tentang perilaku yang dapat diterima dan tidak diterima (unacceptabel behaviour), tidak memiliki disiplin diri, cenderung kurang percaya diri, impulsif, sulit mengambil keputusan tentang diri sendiri.

Pola asuh permisif (permissive parenting), gaya pengasuhan ini dibagi menjadi dua jenis. Pertama, pengasuhan permissive-indulgent yaitu gaya pengasuhan dimana orang tua sangat terlibat dalam kehidupan anak tapi menetapkan batas atau kendali pada anak. Pengasuhan ini diasosiasikan dengan kurangnya pengendalian anak, karena orang tua permissive-indulgent cenderung membiarkan anak melakukan semua yang diinginkan sehingga anak tidak belajar mengendalikan perilakunya sendiri, mendominasi, tidak menaati aturan, kesulitan bergaul dengan teman sebaya, dan anak selalu berharap semua kemauannya dituruti. Kedua, pengasuhan permissive-indifferent yaitu suatu gaya pengasuhan dimana orang tua sangat tidak terlibat dalam kehidupan anak. Anak yang dibesarkan dengan pengasuhan permissive-indifferent cenderung kurang percaya diri, pengendalian diri buruk, tidak memiliki kemampuan sosial, tidak mandiri, tidak dewasa, kemungkinan terasing dari keluarga, dan rasa harga diri rendah.

Berdasarkan kajian teori yang sudah dipaparkan di atas, hubungan antara pola asuh orang tua dengan disiplin belajar siswa tidak signifikan. Orang tua yang akan mendidik dan mengarahkan anak sesuai dengan nilai, norma, dan aturan yang berlaku di masyarakat. Cara mendidik atau pola asuh orang tua berupa ucapan atau tindakan, perhatian, motivasi, dan pendampingan anak nantinya akan berdampak pada sikap dan perilaku anak, salah satunya disiplin belajar. Namun, analisis data menunjukkan penyimpangan dari teori yang ada. Hal ini membuktikan bahwa pola asuh orang tua bukanlah faktor penentu disiplin belajar siswa. Faktor diri sendiri dan lingkungan mendapat tempat yang penting dalaam mempengaruhi disiplin siswa. Selain itu, pola permisif yang diterapkan orang tua membuat siswa tidak memfilter lingkungan yang dijalaninya sehingga cenderung berada pada lingkungan yang salah.

Selanjutnya, dapat ditawarkan beberapa solusi untuk mengatasi persoalan disiplin belajar siswa. Disiplin dapat dilakukan dengan cara memperhatikan siswa dengan menyeluruh, kontak mata dan sapaan, bertanya kepada siswa apa yang paling disukai di sekolah dan bagaimana kelas yang diinginkan, mengetahui penyebab perilaku yang menyimpang, mencari kesepakatan di kelas, dan mencari kesepakatan hukuman atau perlakuan bila siswa melanggar kesepakatan. Hukuman positif atau nonfisik bisa digunakan karena apabila menggunakan hukuman fisik dapat memacu siswa untuk melakukan hal yang sama. Hukuman positif atau nonfisik, misalnya dengan memberi pujian bila melakukan perbuatan baik, memberi contoh perilaku yang diinginkan, bersikap realistis terhadap harapan pada siswa sesuai tingkat usianya, memberi dorongan untuk menyelesaikan masalahnya sendiri, tidak menggunakan teriakan atau ancaman, memberikan pendapat terkait tindakan siswa, menggunakan metode bimbingan dan penyuluhan jika perlu dapat mengundang orang tua siswa, serta biarkan siswa belajar melakukan dan menyelesaikannya sendiri.

Cara efektif menumbuhkan disiplin belajar di sekolah, yaitu (1) guru berdiri di samping pintu kelas untuk menyambut siswa serta mengingatkan PR yang harus sudah selesai dikerjakan, (2) sebelum pelajaran dimulai, guru mengingatkan siswa tentang peraturan dan perilaku di kelas, (3) guru memberikan contoh perilaku baik tersebut, (4) memberikan pujian kepada siswa yang berperilaku baik di kelas dan mengabaikan perilaku buruk siswa, (5) saat siswa jenuh guru memberi kesempatan siswa untuk bersamasama berkeliling kelas atau melakukan hal yang menyenangkan agar siswa semangat belajar, (6) 
memberikan perintah saat semua siswa memperhatikan, dan (7) membantu siswa saat kesulitan serta memberikan semangat atau menepuk punggung pada siswa untuk mengerjakan tugasnya dengan baik (Khalsa, 2008:61-65).

\section{SIMPULAN DAN SARAN}

Berdasarkan hasil penelitian, dapat disimpulkan tiga hal. Pertama, pola asuh orang tua terhadap anak cenderung bersifat permisif. Indikator-indikator, seperti: saat kesulitan mengerjakan ulangan, saya bertanya pada teman, orang tua tidak mengajak anaknya untuk makan bersama di rumah, orang tua menyisihkan sebagian waktunya untuk berkumpul bersama anak-anaknya, orang tua mengajak anak untuk memecahkan masalah secara bersama-sama, orang tua bersikap hangat dan sangat menyayangi anak, orang tua bersikap ramah dan sabar kepada anak, dan orang tua menerima prestasi yang di dapat anaknya, mendapat nilai rata-rata yang baik. Kedua, nilai rata-rata disiplin belajar siswa SMPN 7 Kubung dikategorikan cukup baik, seperti: indikator peralatan alat tulis siswa lengkap, laci meja saya bersih dari sampah, mempersiapkan buku yang akan dibawa ke sekolah, berseragam rapi dan bersih saat berangkat ke sekolah, mengumpulkan tugas yang telah selesai dikerjakan tepat waktu, tidak pulang terlebih dahulu sebelum dipersilahkan oleh guru, memperhatikan pelajaran dengan baik, dan langsung menuju tempat duduk memperoleh nilai rata-rata yang sangat baik. Selain itu, ada beberapa indikator yang berkaitan dengan sikap dan pelanggaran-pelanggaran fasilitas belajar menunjukkan hasil yang tidak baik. Ketiga, tidak terdapat hubungan yang signifikan antara pola asuh dengan disiplin belajar siswa di SMPN 7 Kubung. Oleh sebab itu, perlu disarankan beberapa hal, seperti: (1) guru berdiri di samping pintu kelas untuk menyambut siswa, (2) guru mengingatkan siswa tentang peraturan dan perilaku di kelas, (3) guru memberikan contoh perilaku baik tersebut, (4) memberikan pujian kepada siswa, (5) guru memberi kesempatan siswa agar siswa semangat belajar, (6) memberikan perintah saat semua siswa memperhatikan, dan (7) membantu siswa saat kesulitan belajar.

\section{DAFTAR RUJUKAN}

Apriastuti, D. A. (2013). Analisis Tingkat Pendidikan Dan Pola Asuh Orang Tua Dengan Perkembangan Anak Usia 48-60 Bulan. Jurnal Bidan Prada, 4(01).

Aqib, Zainal. (2011). Pendidikan Karakter membangun Perilaku Positif Anak Bangsa. Bandung: CV.Yrama Widya.

Arikunto, Suharsimi. (2010). Prosedur Peneitian Suatu Pendekatan Praktik. Jakarta: PT. Rineka Cipta.

Desmita. (2005). Psikologi Pendidikan. Bandung: PT Remaja Rosdakarya.

Edwards, Drew. (2006). Ketika Anak Sulit Diatur. Bandung: PT Mizan Pustaka.

Fitriana, V. (2011). Gambaran pola asuh keluarga pada pasien skizofrenia paranoid (studi retrospektif) di RSJD Surakarta.

Fortuna, F. (2012). Hubungan pola asuh otoriter dengan perilaku agresif pada remaja.

Gunarsa, Yulia. (2002). Psikologi Anak dan Remaja. Jakarta: BPK Gunung Mulia.

Is Pratiwi, N. (2012). Pola Asuh Anak pada Pernikahan Beda Agama.

Khairunnisa, A. (2013). Hubungan religiusitas dan kontrol diri dengan perilaku seksual pranikah remaja di MAN 1 Samarinda. Ejournal psikologi, 1(2), 220-229.

Khalsa, Sri. (2008). Pengajaran Disiplin dan Harga Diri: Strategi, Anekdot, dan Pelajaran Efektif untuk Keberhasilan Manajemen Kelas. Jakarta: PT Indeks.

Koesoema, Doni. (2007). Pendidikan Karakter. Jakarta: PT.Grasindo.

Kusumaningtyas, L. E. (2015). Dampak Overprotektif Terhadap Perkembangan Kemandirian Anak. Widya Wacana, 10(1).

Marijan. (2012). Metode Pendidikan Anak. Yogyakarta: Sabda Media.

Safitri, Y., \& Hidayati, E. (2013). Hubungan Antara Pola Asuh Orang Tua Dengan Tingkat Depresi Remaja di SMK 10 November Semarang. Jurnal Keperawatan Jiwa, 1(1).

Santrock, John. (2007). Perkembangan Anak. Jakarta: Erlangga.

Sari, Devita Rima. (2015). "Hubungan Pola Asuh Orang Tua dengan Disiplin Belajar Siswa Kelas IV dan V Sekolah Dasar Negeri Se-Gugus I Sidoarum Kecamatan Godean Kabupaten Sleman.” Skripsi. Yogyakarta: UNY.

Sulistyowati, Endah. (2012). Implementasi Kurikulum Pendidikan Karakter. Yogyakarta: PT Citra Adi 


\section{Parama.}

Sutanto, B. C. (2014). Perancangan Kampanye Sosial Pentingnya Waktu Bersosialisasi dan Bermain Anak Usia 6-10 Tahun. Jurnal DKV Adiwarna, 1(4), 12.

Thalib, Syamsul Bachri. (2013). Psikologi Pendidikan Berbasis Analisis Aplikatif. Jakarta: Kencana.

Wahib, A. W. A. (2015). Konsep Orang Tua Dalam Membangun Kepribadian Anak. Jurnal Paradigma Institut, 1(1).

Yusuf, LN. (2004). Psikologi Perkembangan Anak dan Remaja. Bandung: PT Remaja Rosdakarya.

Zuriah, Nurul. (2007). Pendidikan Moral dan Budi Pekerti dalam Perspektif Perubahan. Jakarta: PT Bumi Aksara. 